\title{
Contemporary Challenges of Online Copyright Enforcement in India
}

\author{
Arpan Banerjee
}

\begin{abstract}
This chapter discusses legal strategies to enforce copyright online in India, with a focus on the film industry. The chapter begins by acknowledging various limitations of online copyright enforcement. Then, in Sect. 2, the chapter provides a broad overview of the landscape concerning film piracy in India. In Sect. 3, the chapter discusses a proposed (and unimplemented) recommendation to target end-users in India. In Sect. 4, the chapter discusses recent developments concerning website-blocking injunctions, which is a strategy that the industry has consistently pursued in recent years. In Sect. 5, the chapter discusses the adsupported financial model of pirate websites, referencing a study conducted in India. The chapter concludes by reflecting on the efficacy of non-litigious measures, such as the targeting of ad-supported piracy and negotiations with search engines.
\end{abstract}

\section{Keywords}

India $\cdot$ Copyright $\cdot$ Internet $\cdot$ Piracy $\cdot$ Film $\cdot$ Website blocking $\cdot$ Ad-supported piracy

\author{
A. Banerjee $(\square)$ \\ Jindal Global Law School, Sonipat, Haryana, India \\ University of New South Wales, Sydney, Kensington, Australia \\ e-mail: abanerjee@jgu.edu.in
}




\section{Introduction}

Legal concerns regarding online copyright infringement date back to the first half of the 1990s, when even dial-up Internet was at a nascent stage. The first Clinton administration - at the initiative of Vice President Al Gore-formed the Information Infrastructure Task Force (IITF), to articulate the US government's vision for the so-called National Information Infrastructure (NII). As a part of this initiative, a working group submitted a report, in 1995, discussing the impact of the Internet (then in its infancy) on copyright law. The report presciently observed:

The NII has tremendous potential to improve and enhance our lives. It can increase access to a greater amount and variety of information and entertainment resources that can be delivered quickly and economically from and to virtually anywhere in the world in the blink of an eye. For instance, hundreds of channels of "television" programming, thousands of musical recordings, and literally millions of "magazines" and "books" can be made available to homes and businesses across the United States and around the world. ${ }^{1}$

The report acknowledged that the growth of the Internet could "upset the balance" between copyright owners and users but felt that the challenge could be addressed by "no more than minor clarification and limited amendment" to existing copyright legislation. ${ }^{2}$ The report's main recommendations were that traditional rights of distribution and performance be widened to include the digital transmission of works. ${ }^{3}$ The same year, in one of the earliest law review articles on the subject, Jane Ginsberg advanced a similar view. ${ }^{4}$

Today, nearly 25 years later, the online piracy environment has changed in at least four major ways compared to the early dial-up Internet era, owing to faster and cheaper broadband connection speeds. First, piracy concerns in the dial-up Internet era mostly centred around the sharing of songs in the MP3 format or books in the PDF format, where files were no larger than a few megabytes. Today, the focus has shifted to the sharing of films and television programmes, often in high-resolution formats running into a few gigabytes per file. Second, the growth in websites offering inexpensive (often free) online storage means that vast numbers of such files can be uploaded and shared with ease. This contrasts with the dial-up era, when copying large video files onto CDs and other physical storage devices was the usual and practical method of distributing them. Third, from an era where users could only access low-quality streaming content using software like RealPlayer and Windows Media Player, the Internet has now progressed to a stage where high-resolution content can be easily shared and accessed through YouTube, Dailymotion and Vimeo or local variants of such websites (such as Youku in China). Fourth, Internet

\footnotetext{
${ }^{1}$ Information Infrastructure Task Force (1995). Intellectual Property and the National Information Infrastructure: The Report of the Working Group on Intellectual Property Rights, p. 8.

${ }^{2}$ Ibid at 14,17 .

${ }^{3}$ Ibid at 213.

${ }^{4}$ Ginsburg, J. 1995. Putting Cars on the "Information Superhighway": Authors, Exploiters, and Copyright in Cyberspace. Columbia Law Review 95: 1466, 1482.
} 
access in developing countries and emerging economies has widened greatly, to the point where China ranks first and India second in terms of numbers of Internet users. Other economies in the top ten include Brazil, Russia and Indonesia. ${ }^{5}$ This has led to a significant amount of piracy occurring across borders. ${ }^{6}$

Notwithstanding the above, it can be argued that the views advanced by the IITF Working Group and Ginsberg still hold good today. Many copyright laws worldwide date back to the dial-up era, simply expanding the applicability of traditional rights in an online environment. Yet, they are arguably sufficient to target almost every type of major infringing activity online (although sometimes requiring judicial creativity in their application). If there is dissatisfaction with the prevalence of online piracy, it arguably pertains less to "law lag" (i.e. the principle that the law always lags behind technology ${ }^{7}$ ) than to issues simply beyond the scope of law. The hard reality is that the enormous global scale of global Internet usage and filesharing means that piracy can at best be curbed in spurts. Furthermore, to quote the High Court of Ireland, "Among younger people, so much has the habit grown of downloading copyright material from the internet that a claim of entitlement seems to have arisen to have what is not theirs for free" ${ }^{8}$ In this scenario, there are serious limits to what the law can achieve. For India's film industry, which this chapter will focus on, there are three factors that especially curb the utility of online copyright enforcement - the prevalence of physical piracy, the hosting of pirated content in servers outside India, and, above all, a general deficit of infrastructure in the civil and criminal justice system.

With reference to the first factor, in the late 1990s, when Internet penetration in India was still limited, a government study identified video parlours and cable operators as the major sources for the dissemination of pirated films. The study observed that "[a]ll parties involved in the legitimate transaction of films-from the producers to the theatre owners"- -lost "heavily because of widespread video or cable piracy" and that the government also lost potential tax revenues. ${ }^{9}$ Nearly a decade later, the government constituted a high-level committee on piracy ("Committee") to examine the issue in more detail. In contrast with the older study, the Committee

\footnotetext{
${ }^{5}$ International Telecommunications Union (2017). Internet users by region and country, 2010 2016. https://www.itu.int/en/ITU-D/Statistics/Pages/stat/treemap.aspx

${ }^{6}$ For instance, in 2015, China registered the most number of illegal downloads of the popular US TV show House of Cards, followed by the USA and then closely by India. See Spangler, T. (2015). "House of Cards" Season 3 Pirated, With China Top Country for Downloaders. Variety. http:// variety.com/2015/digital/news/house-of-cards-season-3-pirated-with-china-top-country-fordownloaders-1201444023/

${ }^{7}$ Hurlbut, B. (2015). Remembering the Future: Science, Law, and the Legacy of Asilomar. In Jasanoff, S. \& Kim, S. (Eds.), Dreamscapes of Modernity: Sociotechnical Imaginaries and the Fabrication of Power (pp. 126-151). Chicago: University of Chicago Press. Hurlbut is generally critical of the concept of law lag, stating: "[T]he notion of law lag is an expression of the imaginary of governable technological emergence. Law inevitably lags, and must lag, if science is to be free to generate novelty".

${ }^{8}$ EMI v. Eircom (2010) I.E.H.C. 108, \& 5.

${ }^{9}$ National Productivity Council. (1999). Study on Copyright Piracy in India, p. 14. http://copyright. gov.in/documents/study $\% 20$ on $\% 20$ copyright $\% 20$ piracy $\% 20 \mathrm{in} \% 20 \mathrm{india}$.pdf
} 
noted the rise of Internet penetration in India and predicted that piracy was "set to explode" with the growth of broadband Internet in India. ${ }^{10}$ But while the number of Internet users in India has no doubt grown exponentially since the 1990s, when expressed as a percentage, it still amounts to merely $30 \%$ of India's population. Moreover, connection speeds in India are often slow. In fact, one study estimates that India's 4G download speeds are among the slowest in the world. ${ }^{11}$ Thus, in contrast with developed countries, physical piracy, via sales of DVDs by street vendors, is still a popular form of consumption of pirated cinema in India, greatly defeating the purpose of online enforcement. ${ }^{12}$

With reference to the second factor, the Indian film industry earns substantial revenue from the Indian diaspora, especially in developed countries. Most major Indian films are released in theatres in these countries. These audiences even form the primary target audience for some producers, due to higher ticket prices in comparison to India. ${ }^{13}$ However, there also exist high levels of consumption of pirated films within this audience. ${ }^{14}$ The Indian film industry lacks the resources to enforce its copyright adequately worldwide. While the Indian government has approached foreign governments for assistance on behalf of the film industry, little action seems to have emerged. ${ }^{15}$

With reference to the third factor, as Marc Galanter has observed, Indian laws are "notoriously incongruent" with "attitudes and concerns"16 and that "[d]elays of Bleak House proportions are routine in many sorts of litigation". ${ }^{17}$ According to the Indian government's own data, several million cases are pending before Indian courts, and there exists a severe shortage of judges. ${ }^{18}$ In the context of criminal copyright enforcement, the matter falls under the jurisdiction of state governments rather than the national governments. As a result, copyright enforcement becomes

\footnotetext{
${ }^{10}$ Ministry of Information \& Broadcasting. (2009). Report of the Committee on Piracy, pp. 45-6.

${ }^{11}$ Dovall, P. 2018. 4G speed in India slowest in world. Times of India. https://timesofindia.indiatimes.com/business/india-business/4g-speed-in-india-slowest-in-world/articleshow/63021612. $\mathrm{cms}$

${ }^{12}$ US Trade Representative. (2014). Out-of-Cycle Review of Notorious Markets, p.16 (listing bazaars in India where pirated DVDs are sold); Liang, L. \& Sundaram, R., (2011). India. In Karganis, J. (Ed.), Media Piracy in Emerging Economies (pp. 339-398, 348-50). New York: Social Science Research Council.

${ }^{13}$ Banerjee, A. 2011. A Case for Economic Incentives to Promote "Parallel" Cinema in India. Media \& Arts Law Review 16: 21, 23-6.

${ }^{14}$ For example, according to one report, the hit Bollywood film Kaminey was downloaded illegally 350,000 times within a week of its release, with a third of the downloads originating from outside India. Frater, P. 2009. Online Piracy in India a Global Problem. Hollywood Reporter. http://www. hollywoodreporter.com/news/online-piracy-india-global-problem-92365

${ }^{15}$ Banerjee, A. 2016. Copyright Piracy and the Indian Film Industry: A "Realist" Assessment. Cardozo Arts \& Entertainment Law Journal 34: 609, 639-40.

${ }^{16}$ Galanter, M. (1967). The Uses of Law in Indian Studies. In Language and Areas: Studies Presented to George V. Bobrinskoy (pp. 37-44, 38).

${ }^{17}$ Galanter, M. 2010. World of Our Cousins. Drexel Law Review 2: 365, 368.

${ }^{18}$ Government of India (2012). National Court Management Systems, Policy and Action Plan.
} 
weak in less developed regions, with instances of corruption and inefficiency. ${ }^{19}$ When criminal cases proceed to trial, complainants face further challenges. One report has observed that criminal copyright cases, "most of the time, have not yielded effective and deterrent results", with problems such as accused being awarded bail easily, lengthy delays, loss of evidence, low conviction rates and low amounts of fines where convictions are awarded. ${ }^{20}$ In the context of civil litigation, cases tend to proceed slowly following the interim stage. As the Supreme Court of India has observed, "[I]n the matters of trademarks, copyrights and patents, litigation is mainly fought between the parties about the temporary injunction and that goes on for years and years and the result is that the suit is hardly decided finally". ${ }^{21}$

With the above caveats, this chapter discusses online copyright enforcement in India. In Sect. 2, the chapter provides a broad overview of the landscape concerning film piracy in India. In Sect. 3, the chapter discusses a proposed (and unimplemented) recommendation to target end-users in India. In Sect. 4, the chapter discusses legal issues concerning website-blocking injunctions, which is a strategy that the industry has aggressively pursued in recent years. In Sect. 5, the chapter discusses the issue of ad-supported piracy, which may well be the next battleground for rights owners in India. The chapter concludes by reflecting on the efficacy of nonlitigious measures, such as the targeting of revenue-generating ads and negotiations with search engine websites. Although the focus of this chapter is on the Indian film industry, to a great extent it will automatically subsume the Indian music industry. Unlike in many countries, the majority of Indian films are musicals. Most popular musicians in India release songs as part of film soundtracks. Thus, film consumption in India is frequently synonymous with music consumption, and copyright ownership of films and sound recordings often lie with the same entity. ${ }^{22}$

\section{The Piracy Landscape in India}

The Indian film industry is the world's largest in terms of films produced and tickets sold, ${ }^{23}$ third largest in terms of box-office size ${ }^{24}$ and fastest-growing overall. ${ }^{25}$ Globally, Indian cinema enjoys popularity among the Indian diaspora, as well as

\footnotetext{
${ }^{19}$ Liang \& Sundaram, supra note 12, at 342.

${ }^{20}$ International Intellectual Property Alliance (2014), Special 301 Report on Copyright Protection and Enforcement, p. 43 http://www.iipa.com/rbc/2014/2014SPEC301INDIA.PDF

${ }^{21}$ Vardhman v. Chawalwala (2009) 41 P.T.C. 397, If 3 (S.C.).

${ }^{22}$ See generally, Morcom A. (2007). Hindi Film Songs and the Cinema. London: Ashgate.

${ }^{23}$ UNESCO Institute for Statistics (2014). Diversity and the Film Industry: Analysis of the 2014 UIS International Survey on Feature Film Statistics, p. 9. http://uis.unesco.org/sites/default/files/ documents/diversity-and-the-film-industry-an-analysis-of-the-2014-uis-survey-on-feature-filmstatistics-2016-en_0.pdf

${ }^{24}$ Motion Picture Association of America (2016). Theatrical Market Statistics, p. 7. https://www. mpaa.org/wp-content/uploads/2017/03/MPAA-Theatrical-Market-Statistics-2016_Final.pdf

${ }^{25}$ PricewaterhouseCoopers (2014). Global Entertainment and Media Outlook 2014-2018: India Summary, pp. 3-4. https://www.pwc.com/gx/en/global-entertainment-media-outlook/assets/
} 
among non-Indian populations in certain parts of Asia and Africa, and forms a component of India's global "soft power". ${ }^{26}$ However, the industry suffers from high levels of piracy. According to an industry study, piracy causes the Indian film industry annual financial losses of around US\$1 billion, along with around 600,000 annual job losses. ${ }^{27}$ Even if one may dispute how such figures have been computed, it is undeniable that a culture of piracy is widely prevalent throughout India. Pirated DVDs are openly sold in markets in Indian cities, while illegal file-sharing and downloading are common.

There are multiple ways in which pirated copies of films are produced and distributed online in India (as in many other countries). Of these, four are noteworthy. First, prints of films have been leaked internally by entities within the production and distribution chain. ${ }^{28}$ Second, pre-release prints of films (called "screeners") have been leaked via film festivals, industry insiders and even the Indian film classification board.$^{29}$ Third, at the post-release stage, film pirates have used camcorders inside theatres to copy films and subsequently distribute them online. With advances in the quality of mobile phone cameras, pirates are increasingly using mobile phones to record films, making them difficult to detect. ${ }^{30}$ Fourth, also at the post-release stage, films can simply be copied from legitimate sources and shared online, whether from DVDs or streaming services like Netflix and Amazon Prime.

The motives for the above acts can vary. There have been instances where individuals have shared copyrighted content simply out of enthusiasm and without any apparent financial motive. However, a significant amount of piracy is motivated by financial gain. The Committee has described piracy as a "high rewards" business. ${ }^{31}$ Some years ago, a single raid against a prominent pirate in India reportedly yielded pirated DVDs worth over US\$ 1 million. ${ }^{32}$ Of late, online piracy yields significant revenues through advertising. In 2014, a report by a then British member of

\section{indian-summary.pdf}

${ }^{26}$ Thussu, D. (2013). Communicating India's Soft Power: Buddha to Bollywood, pp. 127-154. Palgrave MacMillan: London.

${ }^{27}$ US-India Business Council \& Ernst \& Young (2009). The Effects of Counterfeiting and Piracy on India's Entertainment Industry, pp. 3, 31.

${ }^{28}$ For example, clips from Baahubali 2, a big-budget film, were leaked online before the film's release by a young graphic designer who was a part of the editing team. See Roy, G. 2016. Baahubali 2 War Sequence Leaked, Graphic Designer Arrested. NDTV. http://movies.ndtv.com/ regional/baahubali-2-scenes-leaked-graphic-designer-arrested-1628731

${ }^{29}$ For example, a major Bollywood film, Udta Punjab, was leaked online in entirety when the film was pending review with the Indian film classification board. See Datta, A.N. 2016. "Udta Punjab" leak: CBFC claims innocence as all fingers point at them. DNA. http://www.dnaindia.com/entertainment/report-udta-punjab-leak-cbfc-claims-innocence-as-all-fingers-point-at-them-2224252

${ }^{30}$ Pillai, S. 2016. The Piracy Nightmare. The Hindu. http://www.thehindu.com/features/cinema/ The-piracy-nightmare/article14593263.ece

${ }^{31}$ Report of the Committee on Piracy, supra note 10 at 14.

${ }^{32}$ Selvaraj. A. 2013. CB-CID Unearths Rs 7cr Worth Materials from Video Pirate. Times of India. http://timesofindia.indiatimes.com/city/chennai/CB-CID-unearths-Rs- 7 cr-worth-materials-fromvideo-pirate/articleshow/18096084.cms 
parliament, serving as intellectual property advisor to Prime Minister David Cameron, quoted estimates that 600 pirated websites generated over US\$ 200 million through advertising revenues in 2013 , with nearly a third of the advertisements being those of "household" brands. ${ }^{33}$ According to the report, most businesses were unaware of their advertisements appearing on such websites. ${ }^{34}$ In India, a study by the Federation of Indian Chambers of Commerce and Industry (FICCI) and Strategic IP Information (SIPI) tracked 1143 pirate websites offering Indian films and found $73 \%$ to be supported by advertisements. Over half were found to be advertisements of well-known brands. ${ }^{35}$

A section of academicians and activists in India have viewed film piracy as an altruistic activity. For example, Lawrence Liang has declared himself to be "a defender of film piracy", ${ }^{36}$ while the Alternative Law Forum (an organisation promoting open access) has dismissed WIPO's advocacy efforts against piracy. ${ }^{37}$ The most common justification advanced by sympathisers of piracy is that it facilitates access to culture. This was even an argument once advanced by defendants, accused of running an unlicensed DVD rental, in a copyright infringement case. ${ }^{38}$ However, the ad-supported financial model of pirate websites (discussed later in Sect. 5) must bring into question how altruistic the motives of pirates actually are. To illustrate, in 2014, two websites offering pirated versions of a popular Bollywood film were tracked down to pirates based in Latvia, ostensibly with little cultural affinity towards India and motivated entirely by profit. ${ }^{39}$ In the FICCI-SIPI study, of the websites tracked, the largest number of server locations was in North America, then Europe and then Asia. ${ }^{40}$ Furthermore, unlike a decade ago, there are now many avenues for accessing licensed content in India at nominal prices, through streaming websites like YouTube, Netflix and Hotstar (an India-focused website run by the Star television network).

\footnotetext{
${ }^{33}$ Weatherley, M. (2014). "Follow the Money": Financial Options to Assist in the Battle Against Online IP Piracy. http://www.olswang.com/media/48204227/follow_the_money_financial_ options_to_assist_in_the_battle_against_online_ip_piracy.pdf

${ }^{34} \mathrm{Ibid}$ at 2 (stating, "[I]n the majority of instances, display advertising that appears next to infringing material is not intended by the advertiser, its agency or intermediary companies involved in the trading of advertising").

${ }^{35}$ Federation of Indian Chambers of Commerce (FICCI) and Industry \& Strategic IP Information (SIPI) (2017). Badversiting. http://verisiteglobal.com/Badvertising_Report.pdf

${ }^{36}$ Liang, L. 2014. Insights on Film Piracy. Economic and Political Weekly 47: 29, 30.

${ }^{37}$ Alternative Law Forum. Right02Copy. http://altlawforum.org/productions/right02copy

${ }^{38}$ Warner Bros. v. Santosh 2 M.I.P.R. 25 (2009), II 15. The defendants argued (unsuccessfully) before the court that that they were "solving the problem of an "artificial shortage" of entertainment in India.

${ }^{39}$ Banerjee, supra note 15 .

${ }^{40}$ FICCI \& SIPI, supra note 35, at 20.
} 


\title{
$3 \quad$ Targeting End-Users: A Graduated Response Proposal
}

Indian copyright law recognises the rights of reproduction, distribution and communication to the public, as well as their applicability in an online environment. ${ }^{41}$ There is an absence of Indian case law comprehensively discussing the liability of end-users for downloading infringing content. Outside India, however, there exists ample judicial precedent supporting liability. For example, in the USA, in a wellknown case involving the file-sharing service Napster, it was observed:

\begin{abstract}
Napster users who upload file names to the search index for others to copy violate plaintiffs' distribution rights. Napster users who download files containing copyrighted music violate plaintiffs' reproduction rights. [...] The district court concluded that Napster users are not fair users. We agree. ${ }^{42}$
\end{abstract}

In a later case, it was reiterated: "[D]ownloading copyrighted songs cannot be defended as fair use, whether or not the recipient plans to buy songs she likes well enough to spring for". ${ }^{43}$ In a more recent case, involving movie torrent downloads, the Federal Court of Australia observed that "the downloading of a sliver of the film from a single IP address" constitutes copyright infringement, even if the size of the sliver is "very small", and it infringes the right of communication to the public. ${ }^{44}$ In a decision of the European Court of Justice, an exemption has been provided to Internet users who stream content where only a temporary cached copy is created in the user's hard disk. ${ }^{45}$ But while this would exempt users from liability from viewing pirated streams on websites like YouTube and Dailymotion, the exemption would seemingly not exist if a user actively downloads these videos (e.g. by using websites such as www.keepvid.com) or if a permanent cached copy is created in the user's disk.

There is no reason why the legal position in India should be any different from that above. However, targeting end-users is always an unpopular and controversial strategy anywhere in the world. It has rarely been followed by rights owners in India. In recent years, some developed countries have adopted the so-called "graduated response" systems as a milder way to target end-users. ${ }^{46}$ Graduated response systems can be divided into the "publicly and privately arranged", the former originating in statutes and the latter in agreements between Internet service providers

\footnotetext{
${ }^{41}$ Copyright Act of 1957, s. 14

${ }^{42}$ A\&M Records v. Napster 239 F.3d 1004, 1014-5 (9th Cir. 2001).

${ }^{43}$ BMG Music v. Gonzalez 430 F.3d 888, 890 (7th Cir. 2005).

${ }^{44}$ Dallas Buyers Club v. iiNet (2015) F.C.A. 317, IIII 28-30 (Fed. Ct. Aust.).

${ }^{45}$ Newspaper Licensing Agency v. Meltwater (2014) A.C. 1438, III 26, 27, 29, 30, 33-38, 46, 49-52 (Case C-360/13) (Eur. Ct. Justice).

${ }^{46}$ The countries with such a mechanism currently in place include the USA, UK, France, New Zealand, Ireland, South Korea and Taiwan. See Giblin, R. 2014. Evaluating Graduated Response. Columbia Journal of Law \& Arts 37: 147.
} 
(ISPs) and rights owners. ${ }^{47}$ The common feature of these schemes is that they "generally require that the ISP take some action against users suspected of infringing copyright, ranging from issuing warnings, to collating allegations made against subscribers and reporting to copyright owners, to suspension and eventual termination of service". ${ }^{48}$ Arguments in favour of graduated response systems hold that such schemes can act as "digital scarecrow[s]" and deter large numbers of Internet users from infringing copyright and that they represent a cheaper and fairer alternative to suing individual Internet users. ${ }^{49}$

At present, ISPs and other intermediaries in India are governed by a set of rules requiring them to inform users not to host or upload "any information" that "infringes any...copyright or other proprietary rights". ${ }^{50}$ In case users breach this policy, the ISP or intermediary "has the right to immediately terminate the access or usage rights of" the user. ${ }^{51}$ Although uploading is a natural consequence of using file-sharing software, there is little evidence to suggest that, in the absence of court orders, ISPs have voluntarily disconnected users who upload pirated content by using such software. Indeed, as many subscribers may purchase high-speed Internet connections with the purpose of downloading pirated films, it is questionable whether ISPs even desire to enforce such rules. The Committee accordingly suggested the institution of a "three stage strike model" where "[a]t the first stage, the errant subscriber could be let off with a warning appearing on his screen; at the second stage, a more severe punishment could be given while the third time, the subscriber's services could be disrupted for a few hours or so". ${ }^{52}$

The issue of disconnecting a user is no doubt the most contentious aspect of graduated response systems. The Indian constitution grants all citizens the fundamental right to "freedom of speech and expression", subject only to certain "reasonable restrictions". ${ }^{53}$ The Supreme Court has held that this right includes a "right to... information, knowledge and entertainment" 54 and that the "content of the right... remains the same whatever the means of communication including internet communication". ${ }^{55}$ Therefore, it could be argued that the right to access information

\footnotetext{
${ }^{47}$ Ibid at 153.

${ }^{48}$ Suzor, N. \& Fitzgerald, B. 2001. The Legitimacy of Graduated Response Schemes in Copyright Law. UNSW Law Journal 34:1.

${ }^{49}$ Yu, P. 2010. The Graduated Response. Florida Law Review 62:1374, 1381-3.

${ }^{50}$ Information Technology (Intermediaries Guidelines) Rules 2011, Notification No. G.S.R. 314(E), s. 3(2)(d).

${ }^{51}$ Ibid at s. 3(5).

${ }^{52}$ Report of the Committee on Piracy, supra note 10 at 35-36.

${ }^{53}$ Constitution of India, Article 19.

${ }^{54}$ Secretary, Ministry of Information v. Cricket Association of Bengal (1995) A.I.R. S.C. 1236, II 91.

${ }^{55}$ Shreya Singhal v. India AIR 2015 SC 1523 If 86.
} 
and entertainment through the Internet is a fundamental right under the Indian Constitution.

Outside India, the High Court of Ireland has observed that while disconnection is a "serious sanction", it does not completely deprive persons of Internet access, as they "have only to walk down to their local town centre" and use a cybercafé. ${ }^{56}$ However, France's highest court, the Constitutional Council, struck down as unconstitutional a provision in the first version of France's graduated response system, under which subscribers could be disconnected for up to 1 year and barred from entering into contracts with other ISPs during this period. ${ }^{57}$ The fact that the Committee referred to "disruption" for a few hours, rather than a lengthy "disconnection", indicates that the Committee may have been hinting at bandwidth reduction rather than outright disconnection. Such a measure would perhaps be easier to defend as a permissible "reasonable restriction".

It has also been argued that graduated response systems deny "end-users due process by subjecting them to unverified suspicion of infringing activities", and the technology used to identify infringing users is also not accurate. ${ }^{58}$ In Ireland, for example, a technical glitch led to an ISP incorrectly sending almost 400 subscribers copyright infringement notifications. ${ }^{59}$ In France, the Constitutional Council held that by "reversing the burden of proof" and fixing "presumption of guilt" on Internet user, the first version of France's graduated response system had contravened the French constitution. ${ }^{60}$ An easy way to overcome this problem could be to dispense with the penalty of disruption altogether and simply send users persuasive warnings. Such a model has been attempted in the UK. However, the efficacy of such a model is yet to be determined. One critic has described the UK model as "toothless" ${ }^{61}$

Even if a graduated response mechanism may be constitutionally defensible in India, such a measure would still be unpopular among the public, especially as Internet access is still restricted to a minority of India's population and out of reach of economically weak sections. Furthermore, it is not unreasonable to assume that, among poorer sections of the population, several users may share an Internet connection between themselves, meaning that non-infringers may be penalised. It is, therefore, not a surprise that the Committee's proposal has not found legislative or political support. Instead, rights owners have preferred to use website-blocking injunctions as an anti-piracy strategy. However, the question of targeting end-users has again reared its head, following an order of the Delhi High Court in a recent website-blocking case. The court observed that "since website blocking is a

\footnotetext{
${ }^{56}$ E.M.I. v. Eircom (2010) I.E.H.C. 108, II 9.

${ }^{57}$ Conseil Constitutionnel [Constitutional Court] decision No. 2009-580, June 10, 2009, J.O. 9675 (Fr.) ("HADOPI case"), translated in Act Furthering the Diffusion and Protection of Creation on the Internet, Décision n ${ }^{\circ}$ 2009-580, 4 (June 10, 2009), IITI 9-10, 19, 39 available at http://www. conseil-constitutionnel.fr/conseil-constitutionnel/root/bank/download/2009580DC2009_580dc. pdf

${ }^{58} \mathrm{Yu}$, supra note 49 , at $1394-6$.

${ }^{59}$ E.M.I. v. Eircom (2012) I.E.H.C. 264, IIII 1.1-1.3.

${ }^{60}$ HADOPI case, supra note 57 , at TIII 18,39

${ }^{61}$ Solon O. (2014). ISPs Launch Toothless Four Strikes Anti-Piracy Initiative. Wired. http://www. wired.co.uk/news/archive/2014-07/21/four-strikes-copyright
} 
cumbersome exercise" and the majority of downloaders are "youngsters" who may be unaware of copyright law, the government should frame a policy where users are warned "if technologically feasible in the form of e-mails, or pop-ups or such other modes", and fined in the event of not heeding the warnings ${ }^{62}$.

\section{$4 \quad$ Website-Blocking Injunctions}

As mentioned earlier, what most plaintiffs in civil infringement actions in India realistically look for is an interim injunction. Here, the Delhi High Court has been liberal in granting such injunctions speedily and ex parte, through the so-called "John Doe" orders. A John Doe order is an order restraining anonymous infringers. It is often referred to as an "Ashok Kumar" order in India. The first such order in India was passed by the Delhi High Court, in a case involving pirated live broadcasts of the 2002 FIFA World Cup by unlicensed cable operators. The plaintiffs held rights to broadcast the event and had sublicensed those rights to specific cable operators in India. At the time, broadband penetration in India was very low, and streaming technologies were underdeveloped worldwide. Thus, the plaintiffs were focused on curbing television broadcasts. The plaintiffs named a handful of cable operators who were already broadcasting the matches without a licence as defendants but added unknown "Ashok Kumar" parties as remaining defendants. The plaintiffs argued that the "enforcement of rights against cable operators is a virtual nightmare" and that "if they were to wait and identify specific parties and collect evidence of infringement by such specific parties, they would lose a great amount of time". ${ }^{63}$ Citing decisions from the USA, the UK, Canada and Australia, the plaintiffs argued for a John Doe order against the additional, unknown defendants. The court agreed with the plaintiffs' contentions and granted the order. Justice Dalveer Bhandari (who would go on to be appointed to the Supreme Court of India and the International Court of Justice) observed:

The judicial systems of all these countries have basic similarity with our judicial system. Therefore, looking to the extra ordinary facts and circumstances of the case, in the interest of justice the courts in India would also be justified in passing 'John Doe' orders. ... Undoubtedly the cable operators in India have a long history of violating copyrights.... The cable operators are encouraged owing to the unique nature of cable piracy and the unstructured nature of the cable industry, the speed with which any trace of infringement can be erased by the cable operators, enforcement of rights in conservative nature is unlikely to effectively redress the plaintiffs' grievance.$^{64}$

In the context of online piracy, a number of rights owners have obtained broadly worded ex parte John Doe orders from the major High Courts (particularly Delhi) to compel ISPs to pre-emptively block infringing websites - a trend visible from 2011 onwards. In what is thought to be the first of such cases, the Delhi High Court

\footnotetext{
${ }^{62}$ UTV v 1337X.to, Civil Suit No 724/2017, If 104, Delhi High Court, 10 April 2019, https://indiankanoon.org/doc/47479491/.

${ }^{63}$ Taj Television v. Mandal (2003) F.S.R. 22, II 7 (Del. H.C.).

${ }^{64}$ Ibid II II 16, 17.
} 
granted an injunction in connection with a big-budget Bollywood film, Singham. Applying Justice Bhandari's decision in an online context, the court stated:

[D]efendants, and other unnamed and undisclosed persons, are restrained from communicating or making available or distributing, or duplicating, or displaying, or releasing, or showing, or uploading, or downloading, or exhibiting, or playing, and/or defraying the movie "Singham" in any manner without proper license from the plaintiff or in any other manner which would violate/infringe the plaintiff's copyright in the said cinematograph film "Singham" through different mediums like CD, DVD, Blue-ray, VCD, Cable TV, DTH, Internet, MMS, Tapes, Conditional Access System or in any other like manner. ${ }^{65}$

Thus, the court passed a very broad order encompassing various actors in the online piracy chain, from those indulging in camcording to uploaders and downloaders, as well as actors involved in physical piracy. This order was followed by a large number of similar orders in the coming months and years, using similar language. ${ }^{66}$

Unsurprisingly, ISPs did not take kindly to such orders being passed against them ex parte. An association of ISPs wrote to the Indian government complaining that various law firms had been sending ISPs legal notices annexing copies of John Doe orders and that the government's Department of Telecommunications (DoT) notification was the correct authority to instruct a website to be blocked ${ }^{67}$ However, a film company countered this by impleading the DoT as an additional party in a subsequent suit before the Delhi High Court. The court held that even the DoT was required to block "various websites (named and un-named)...primarily indulged in hosting, streaming or providing access to infringing and illegal" copies of the film in question. ${ }^{68}$

The wide ambit of such orders has met with considerable criticism. One of the earliest criticisms was that ISPs were blocking entire websites (such as Vimeo and Daily Motion) instead of specific pages within the website hosting infringing content. ${ }^{69}$ In one instance, a consumer court directed an ISP to pay compensation to a

\footnotetext{
${ }^{65}$ Reliance v. Jyoti Cable, Civil Suit No. 1724 of 2011 (Del. H.C., Jul. 20, 2011), http://delhihighcourt.nic.in/dhcqrydisp_o.asp?pn=135357\&yr=2011

${ }^{66}$ See, e.g. Reliance v. Jyoti Cable, Civil Suit No. 2066 of 2011 (Del. H.C., Aug. 26, 2011), http:// delhihighcourt.nic.in/dhcqrydisp_o.asp?pn=173116\&yr=2011 (similarly worded order concerning the Bollywood film Bodyguard); Reliance v. Multivision, Civil Suit No. 3207 of 2011 (Del. H.C., Dec. 19, 2011), http://delhihighcourt.nic.in/dhcqrydisp_o.asp?pn=269404\&yr=2011 (similarly worded order concerning the Bollywood film Don 2). See also John Doe Orders - Stop Piracy, Oct. 8, 2014, NAIK NAIK \& CO., http://naiknaik.com/john-doe-orders (contains a table with details of John Doe orders awarded by courts, including the Bombay, Madras and Calcutta High Courts).

${ }^{67}$ Letter from the Internet Service Providers Association of India to the Secretary, DoT (2011). http://www.ispai.in/UI/uploads/submissionAttach/dot(1).pdf

${ }^{68}$ See, e.g. Fox v. Macpuler, Civil Suit No. 2066 of 2011, If 7 (Delhi High Court, May 14, 2015), http://delhihighcourt.nic.in/dhcqrydisp_o.asp?pn=110404\&yr=2015

${ }^{69}$ Dua, K. 2012. Confusion Reigns as Indian ISPs Block Vimeo, Torrent Websites. NDTV. http:// gadgets.ndtv.com/internet/news/confusion-reigns-as-indian-isps-block-vimeo-torrent-websites-223340. Pawa, N. Update: Files Sharing Sites Blocked In India Because Reliance BIG Pictures Got A Court Order. Medianama. http://www.medianama.com/2011/07/223-files-sharingsites-blocked-in-india-because-reliance-big-pictures-got-a-court-order
} 
subscriber who could not access a website for over a month. ${ }^{70}$ High Courts have since attempted to rectify this flaw. In 2013, the Madras High Court stated that only pages specifically hosting infringing content ought to be blocked, rather than entire websites. $^{71}$ In 2016, the Delhi High Court passed a similar order. ${ }^{72}$ The same year, the Bombay High Court refused to grant a John Doe order, where the plaintiff requested for a block on 800 websites, finding the plaintiff's suit to be "sketchy and formless". ${ }^{73}$ The judge directed the plaintiff to instead produce "a list of individual links to downloads", further stating that "a technically competent officer" of the plaintiff must check "if not all, at least a sufficient sampling of these links so as to warrant the grant of an injunction". ${ }^{74}$

However, the Delhi and Bombay High Courts both later backtracked. The Delhi High Court recalled its order and held that "rogue websites" indulging in "rank piracy" ought to be blocked outright, rather than specific pages within the website. ${ }^{75}$ The Bombay High Court, in a subsequent order by the same judge, blocked all websites submitted by the plaintiff in a list, numbering $110 .{ }^{76}$ The list of websites included full websites, such as www.limetorrents.cc, www.thepiratebay.org and www.ugtorrents.com, instead of specific pages. Recently, amidst uncertainty regarding the actual legal position, the popular website www.archive.org (which hosts thousands of valuable historical materials in the public domain) was blocked in entirety by ISPs, following a John Doe order of the Madras High Court. Some users had apparently uploaded pirated copies of two films on the website. However, the plaintiffs named the website in entirety in the infringement suit, and the court granted the plaintiffs the relief they sought without any rider distinguishing the website in entirety versus the infringing pages within it. ${ }^{77}$

\footnotetext{
${ }^{70}$ Vinay v. Airtel, Consumer Complaint 226 of 2012 (District Consumer Disputes Redressal Forum, Shimoga, Aug. 3, 2012), http://164.100.72.12/ncdrcrep/judgement/18533120803153733968226202.pdf

${ }^{71}$ Vodafone v. R.K. Productions (2013) 54 P.T.C. 149, II 4 (Mad. H.C.) (quoting an earlier order where the court had stated that "the interim injunction is granted only in respect of a particular URL where the infringing movie is kept and not in respect of the entire website".).

${ }^{72}$ DEITY v. Star, First Appeal Order No. 57 of 2015 (Del. H.C. March 10, 2016), http://delhihighcourt.nic.in/dhcqrydisp_o.asp?pn=54187\&yr=2016

${ }^{73}$ Balaji Motion Pictures v. Bharat Sanchar Nigam, Civil Suit No. 694 of 2016 (Bom. H.C. July 1, 2016), II 6, http://spicyip.com/wp-content/uploads/2016/07/Great-Grand-Masti-1.pdf

${ }^{74}$ Ibid at IIII 7-8.

${ }^{75}$ DEITY v. Star, Review Petition in First Appeal Order No. 57 of 2015, II 14(Del. H.C. July 29, 2016), available at http://lobis.nic.in/ddir/dhc/PNJ/judgement/29-07-2016/ PNJ29072016REVIEWPET1312016.pdf

${ }^{76}$ Balaji Motion Pictures v. Bharat Sanchar Nigam, Civil Suit No. 694 of 2016 (Bom. H.C. July 8, 2016), If 4, http://s3.documentcloud.org/documents/2944079/Great-Grand-Masti-Order-Dated8th-July-2016.pdf

${ }^{77}$ Internet Archive blocked in India, thanks to Lipstick Under My Burkha \& Shah Rukh Jab Harry Met Sejal. 2017. India Today. https://www.indiatoday.in/technology/news/story/internet-archiveblocked-in-india-thanks-to-lipstick-under-my-burkha-and-shah-rukh-jab-harry-met-sejal1029036-2017-08-10
} 


\section{$5 \quad$ Ad-Supported Piracy}

The prevalence of ad-supported piracy has been highlighted in recent studies. This section discusses the FICCI-SIPI study in more detail. The study is only among a handful conducted on the subject worldwide and perhaps the only one in India. As mentioned earlier, the study tracked 1143 pirate websites offering pirated copies of Indian films. These roughly fell into five categories-torrent and other peer-to-peer file-sharing websites, direct download websites, linking websites and streaming websites. The study found 786 different entities advertising on 835 websites. Of this number, $46 \%$ concerned categories such as adult dating, pornography, unregulated products and gambling. The remaining $56 \%$ concerned mainstream products and services. ${ }^{78}$ The latter spanned industries like telecommunications, automobiles, entertainment and retail and included ads for well-known brands like Lufthansa, AirAsia, Nissan, Hyundai, Religare (an Indian financial services group) and Flipkart (a popular Indian online retail website) ${ }^{79}$

The study blamed the appearance of such ads on the way digital advertisers function. The study reported that up to $85-90 \%$ of the digital advertising budget of brands was spent on search engines, social media and legitimate livestreaming platforms. However, the remaining amount was funnelled by ad agencies or marketing teams to "ad networks that provide cheap and efficiency driven media campaigns", such as Google AdSense, DoubleClick (a subsidiary of Google), PopAds, Propeller Ads, BlueKai, AppNexus and Lotam. ${ }^{80}$ These networks typically operate on a costper-click basis and exercise low levels of control. ${ }^{81}$ This means, for example, that an ad for Lufthansa placed through such networks may appear on a pirate website offering a copy of the newest Avengers film, rather than a news website, if the former attracts 100,000 visitors a day, while the latter attracts 10,000 a day.

In a report titled How Google Fights Piracy, Google has stated that it "takes the challenge of online piracy seriously" and is "a leader in rooting out and ejecting rogue sites" from ad networks. ${ }^{82}$ Google has claimed that it has terminated over 11,000 AdSense accounts for copyright violations. ${ }^{83}$ However, the FICCI-SIPI study found that Google and DoubleClick collectively provided ad network services to over half the sample websites in the study, with AdSense supplying nearly $20 \%{ }^{84}$ This may suggest that either Google has not devoted much attention to concerns of

\footnotetext{
${ }^{78}$ FICCI \& SIPI, supra note 35 , at pp. $4-5$.

${ }^{79}$ Ibid at $40-42$.

${ }^{80}$ Ibid at 6 .

${ }^{81}$ Ibid.

${ }^{82}$ Google, How Google Fights Piracy 9 (2016). https://drive.google.com/ file/d/0BwxyRPFduTN2TmpGajJ6TnRLaDA/view

${ }^{83}$ Ibid at pp. 4, 16.

${ }^{84}$ FICCI \& SIPI, supra note 35 , at p. 7.
} 
Indian copyright owners or that the sheer scale of piracy means that AdSense accounts violating copyright keep proliferating rapidly. Either way, it clearly demonstrates that income is generated from the piracy of Indian films. While this income, as demonstrated by the FICCI-SIPI study, only draws a small chunk of the digital advertising budget of corporations, it may be considered large in relation to the minimal investment made by pirate websites and the large number of viewers such websites may attract (thus maximising returns from a cost-per-click ad policy).

Yet, even if Google and reputed brands address the problem more seriously and choke funding for pirate websites, it is important to remember that, per the FICCISIPI study, almost half the ads were from dodgy businesses. In India, for example, pornography is technically illegal, while gambling is banned in virtually every Indian state. It is doubtful whether a pornography or gambling website would be as conscious of its brand reputation and prestige as a mainstream corporation would. For such businesses, pirate websites may actually be the best way to advertise their products and services to the youth. Thus, attempting to curb piracy by throttling ad revenues may only be a partly successful strategy.

\section{Conclusion}

The chapter began by drawing attention to the fact that there are limits to how the law can curb online piracy. Enforcement in India presents additional obstacles. In this context, rights owners have carved out website-blocking injunctions as a convenient strategy, which has certainly yielded benefits. Nevertheless, this is still not an ideal remedy. In the absence of judicial authority, especially a Supreme Court decision, laying down the exact criteria for blocking websites in entirety versus specific infringing pages, it is still open to judges to be cautious and insist on blocking specific infringing pages only. In such a situation, a pirate can easily migrate to a different, unblocked page within the same website. Furthermore, even if judges block websites in entirety, this can still allow the blocked website to shift to a different website altogether. For example, a pirated music website blocked by the Calcutta High Court did precisely this. The court ordered the blocking of the website www. songs.pk, with the rider that the "order of blocking should be confined to" that specific website and "should not otherwise interfere with internet service" ${ }^{85}$ The website subsequently migrated to the website www.songspk.pk. ${ }^{86}$ In the time that a rights owner approaches a court for a second time to block a new website, a substantial amount of piracy may already have occurred.

\footnotetext{
${ }^{85}$ Sagarika v. Dishnet, Civil Suit 23 of 2012 (Cal. H.C., Jan. 27, 2012).

${ }^{86}$ Saxena, A. 2012. Songs.Pk Relaunched as Songspk.pk. Mediaama http://www.medianama. com/2012/03/223-songs-pk-relaunched-as-songspk-pk-ad-networks
} 
Additionally, questions should be raised about the manner in which legitimate websites, such as www.archive.org., were blocked. Although it is probable that many judges are not expert Internet users and tend to give plaintiffs the benefit of doubt, the blocking of legitimate websites can constitute a violation of consumer rights and even a violation of the right to freedom of expression.

Amidst this dilemma, rights owners can perhaps explore non-litigious strategies as a more efficient and less contentious measure. For instance, online piracy is increasingly being viewed as a money laundering and tax evasion issue, where pirates profiting from advertisements can use payment gateways to stay anonymous. In the UK, the government has established the Police Intellectual Property Crime Unit (PIPCU). The PIPCU performs a range of anti-piracy functions, notable among which are efforts to disrupt the revenue stream of pirate websites ${ }^{87}$ Recently, following reports of the widespread piracy of Telugu-language films, the state of Telangana in India established the Telangana Intellectual Property Crime Unit (TIPCU), modelled on the PIPCU ${ }^{88}$ Following Telangana, the state of Maharashtra (which is home to Bollywood) announced the establishment of the Maharashtra IP Crime Unit (MIPCU) ${ }^{89}$ By bypassing courts and working with police officials likely to be more knowledgeable about cybercrime and technology, the industry can possibly counter piracy more efficiently.

Another strategy for rights owners could be to approach the Advertising Standards Council of India (ASCI), a self-regulatory body monitoring misleading advertisements, and alert well-known corporations to the problem of their advertisements appearing on pirate websites. Legally, there is no requirement regarding the medium through which traders can advertise their products in India, and the matter would not directly be under the ASCI's ambit. But this does not preclude rights owners from lobbying with the ASCI to initiate discussion among advertisers. In the USA, a joint effort by the Association of National Advertisers, the American Association of Advertising Agencies and the Interactive Advertising Bureau has resulted in the formation of the Trustworthy Accountability Group. This initiative has, according to one study, significantly reduced ad revenues for pirate websites in the USA, curbing revenues by over US $\$ 100$ million. ${ }^{90}$ Possibly, the ASCI could initiate a similar measure.

\footnotetext{
${ }^{87}$ Weatherley, supra note 33, at 7-9.

${ }^{88}$ TIPCU to Tackle Online Piracy. 2016. The Hindu. http://www.thehindu.com/news/national/ andhra-pradesh/tipcu-to-tackle-online-piracy/article8771496.ece

${ }^{89}$ Parmar, M. 2017. FICCI Frames'17. Maharashtra to form IP Crime Unit to fight online piracy. Indian Television. TIPCU to Tackle Online Piracy, THE HINDU, June 25, 2016, http://www.thehindu.com/news/national/andhra-pradesh/tipcu-to-tackle-online-piracy/article8771496.ece

${ }^{90}$ Ernst \& Young, Measuring Digital Advertising Revenue to Infringing Sites. (2017) https://www. tagtoday.net/hubfs/Measuring\%20digital\%20advertising \%20revenue $\% 20$ to $\% 20$ infringing $\% 20$ sites.pdf? $\mathrm{t}=1518474032751$
} 
Yet another strategy for rights owners could be to tackle what is arguably the elephant in the room-Google and its ad networks. Recently, Google has initiated measures to block hate speech websites and prevent advertisements from showing up on these websites. This measure was taken under pressure from corporations displeased at their advertisements inadvertently appearing on such websites. ${ }^{91}$ Copyright owners could enter into discussion with Google for similar technological measures with respect to pirated content. However, copyright infringement is undoubtedly viewed much less seriously than hate speech. Moreover, unlike hate speech, there is a greater degree of acceptance and participation among youth in the consumption of pirated content.

In the end, online piracy is best tackled through a series of measures. However, as this chapter has pointed out, rights owners must be realistic about the limitations of each measure and thus at best only hope to curb the extent of piracy.

\section{References $^{92}$}

Alternative Law Forum. Right02Copy. http://altlawforum.org/productions/right02copy

Banerjee, A. (2011). A case for economic incentives to promote "Parallel" cinema in India. Media \& Arts Law Review, 16(21), 23-26.

Banerjee, A. (2016). Copyright piracy and the Indian film industry: A "Realist Assessment". Cardozo Arts \& Entertainment Law Journal, 34(609), 639-640.

Datta, A. N. (2016). 'Udta Punjab' leak: CBFC claims innocence as all fingers point at them. DNA. http://www.dnaindia.com/entertainment/ report-udta-punjab-leak-cbfc-claims-innocence-as-all-fingers-point-at-them-2224252

Dovall, P. (2018). 4G speed in India slowest in world. Times of India. https://timesofindia.indiatimes.com/business/india-business/4g-speed-in-india-slowest-in-world/articleshow/63021612. cms

Dua,K.(2012).ConfusionReignsasIndianISPsBlockVimeo,TorrentWebsites.NDTV.http://gadgets. ndtv.com/internet/news/confusion-reigns-as-indian-isps-block-vimeo-torrent-websites-223340

Ernst \& Young, Measuring Digital Advertising Revenue to Infringing Sites. (2017). https://www. tagtoday.net/hubfs/Measuring\%20digital\%20advertising\%20revenue\%20to\%20infringing\%20sites.pdf?t=1518474032751

Federation of Indian Chambers of Commerce and Industry \& Strategic IP Information. (2017). Badversiting. http://verisiteglobal.com/Badvertising_Report.pdf

Frater, P. (2009). Online piracy in India a global problem. Hollywood Reporter. http://www.hollywoodreporter.com/news/online-piracy-india-global-problem-92365

Galanter, M. (1967). The uses of law in Indian studies. In Language and areas: Studies presented to George V. Bobrinskoy (pp. 37-44). Chicago: University of Chicago.

Galanter, M. (2010). World of our cousins. Drexel Law Review, 2(365), 368.

Giblin, R. (2014). Evaluating graduated response. Columbia Journal of Law \& Arts, 37, 147.

\footnotetext{
${ }^{91}$ Solon. O. 2017. Google's bad week: YouTube loses millions as advertising row reaches US. Guardian. https://www.theguardian.com/technology/2017/mar/25/google-youtube-advertising-extremistcontent-att-verizon

${ }^{92}$ All online information accessed on February 1, 2018
} 
Ginsburg, J. (1995). Putting cars on the "Information Superhighway": Authors, exploiters, and copyright in cyberspace. Columbia Law Review, 95, 1466.

Google, How Google fights piracy. (2016). https://drive.google.com/ file/d/0BwxyRPFduTN2TmpGajJ6TnRLaDA/view

Hurlbut, B. (2015). Remembering the future: Science, law, and the legacy of Asilomar. In S. Jasanoff \& S. Kim (Eds.), Dreamscapes of modernity: Sociotechnical imaginaries and the fabrication of power (pp. 126-151). Chicago: University of Chicago Press.

Indian Ministry of Information \& Broadcasting. (2009). Report of the committee on piracy.

Information Infrastructure Task Force. (1995). Intellectual property and the national information infrastructure: The report of the working group on intellectual property rights.

International Intellectual Property Alliance. (2014). Special 301 report on copyright protection and enforcement, p. 43. http://www.iipa.com/rbc/2014/2014SPEC301INDIA.PDF

Liang, L. (2014). Insights on film piracy. Economic and Political Weekly, 47, 29-30.

Liang, L., \& Sundaram, R. (2011). India. In J. Karganis (Ed.), Media piracy in emerging economies (pp. 339-398). New York: Social Science Research Council.

Morcom, A. (2007). Hindi film songs and the cinema. London: Ashgate.

Motion Picture Association of America. (2016). Theatrical market statistics. https://www.mpaa. org/wp-content/uploads/2017/03/MPAA-Theatrical-Market-Statistics-2016_Final.pdf

National Productivity Council. (1999). Study on copyright piracy in India. http://copyright.gov.in/ documents/study\%20on\%20copyright\%20piracy\%20in\%20india.pdf. Accessed 1 Feb 2018.

Parmar, M. (2017). FICCI Frames'17. Maharashtra to form IP Crime Unit to fight online piracy. Indian Television. TIPCU to tackle online piracy, THE HINDU, June 25, 2016. http://www. thehindu.com/news/national/andhra-pradesh/tipcu-to-tackle-online-piracy/article8771496.ece

Pawa, N. Update: Files sharing sites blocked in India because reliance BIG pictures got a court order. Medianama. http://www.medianama.com/2011/07/223-files-sharing-sites-blocked-inindia-because-reliance-big-pictures-got-a-court-order. Accessed 1 Feb 2018.

Pillai, S. (2016). The piracy nightmare. The Hindu. http://www.thehindu.com/features/cinema/ The-piracy-nightmare/article14593263.ece

PricewaterhouseCoopers. (2014). Global entertainment and media outlook 2014-2018: India summary. https://www.pwc.com/gx/en/global-entertainment-media-outlook/assets/indiansummary.pdf

Roy, G. (2016). Baahubali 2 war sequence leaked, Graphic designer arrested. NDTV. http://movies.ndtv.com/regional/baahubali-2-scenes-leaked-graphic-designer-arrested-1628731

Saxena, A. (2012). Songs.Pk Relaunched as Songspk.pk. Mediaama. http://www.medianama. com/2012/03/223-songs-pk-relaunched-as-songspk-pk-ad-networks

Selvaraj. A. (2013). CB-CID Unearths Rs 7cr worth materials from video pirate. Times of India. http://timesofindia.indiatimes.com/city/chennai/CB-CID-unearths-Rs-7cr-worth-materialsfrom-video-pirate/articleshow/18096084.cms

Solon O. (2014). ISPs launch toothless four strikes anti-piracy initiative. Wired. http://www.wired. co.uk/news/archive/2014-07/21/four-strikes-copyright

Solon, O. (2017). Google's bad week: YouTube loses millions as advertising row reaches US. Guardian. https://www.theguardian.com/technology/2017/mar/25/ google-youtube-advertising-extremist-content-att-verizon

Suzor, N., \& Fitzgerald, B. (2001). The legitimacy of graduated response schemes in copyright law. UNSW Law Journal, 34, 1.

Thussu, D. (2013). Communicating India's soft power: Buddha to Bollywood (pp. 127-154). London: Palgrave MacMillan.

UNESCO Institute for Statistics. (2014). Diversity and the film industry: Analysis of the 2014 UIS international survey on feature film statistics. http://uis.unesco.org/sites/default/files/documents/diversity-and-the-film-industry-an-analysis-of-the-2014-uis-survey-on-feature-filmstatistics-2016-en_0.pdf 
US Trade Representative. (2014). Out-of-cycle review of notorious markets.

US-India Business Council \& Ernst \& Young. (2009). The effects of counterfeiting and piracy on India's entertainment industry (pp. 3, 31).

Weatherley, M. (2014). "Follow the Money": Financial options to assist in the battle against online IP piracy. http://www.olswang.com/media/48204227/follow_the_money_financial_ options_to_assist_in_the_battle_against_online_ip_piracy.pdf

Yu, P. (2010). The graduated response. Florida Law Review, 62(1374), 1381-1383.

Open Access This chapter is licensed under the terms of the Creative Commons Attribution 4.0 International License (http://creativecommons.org/licenses/by/4.0/), which permits use, sharing, adaptation, distribution and reproduction in any medium or format, as long as you give appropriate credit to the original author(s) and the source, provide a link to the Creative Commons license and indicate if changes were made.

The images or other third party material in this chapter are included in the chapter's Creative Commons license, unless indicated otherwise in a credit line to the material. If material is not included in the chapter's Creative Commons license and your intended use is not permitted by statutory regulation or exceeds the permitted use, you will need to obtain permission directly from the copyright holder.

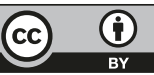

